\title{
Is fundamentele navorsing 'n luukse vir 'n Derdewêreldland?
}

Die voortdurende woelinge in die Suid-Afrikaanse samelewing word gekenmerk deur ekonome en politici se worstelings met allerlei modelle om sowel die Eerste- as Derdewêreldgemeenskappe van ons land in een staatkundige en ekonomiese struktuur te akkommodeer. Dit is insiggewend watter gelyktydige uitsprake daar oor die rol van navorsing in die Suid-Afrikaanse volkshuishouding gemaak word.

Die onbevange luisteraar hoor naamlik 'n byna oorweldigende koor stemme van owerheidsweë en elders wat die lof van die praktiesgerigte korttermynnavorsing, met onmiddellik voorsienbare toepassingsmoontlikhede, besing. Hierdie ondersoekaktiwiteite sou dan by uitstek pas by 'n Derdewêreldland se omstandighede en sou bowendien die teelaarde skep vir nuwe nywerheidsproduksie en vir werkskepping, en sou Suid-Afrika op internasionale vlak industrieel kompeterend hou. Die President van die WNNR, dr. Chris Garbers, som dit raak op: "Generally speaking the present climate in South Africa favours the use of funds for supporting practical, utilitarian development." 1 Die rol van fundamentele navorsing word in baie uitsprake implisiet as van ondergeskikte belang getipeer of selfs in soveel woorde omskrywe as 'n elitistiese Eerstewêreldluukse wat ons ons in 'n Derdewêreldmilieu nie kan veroorloof nie.

Hierteenoor is daar egter terselfdertyd Britse pogings, van dusver ongekende omvang, om hul land tegnologies mededingender te maak deur hernuwing van sy basiese navorsingsgrondslag. ${ }^{2}$ Befondsing van navorsing neem in Japan jaarliks toe. Volgens onlangse berigte $^{3}$ is daar egter heelwat ontstemming by Japanse regeringsinstansies omdat slegs 'n klein persentasie van hierdie fondse vir basiese navorsing aangewend word. Hulle wil veel groter nadruk op fundamentele navorsing en skeppende denke hê4.5 ter voorbereiding vir die eise wat die een-en-twintigste eeu aan alle geïndustrialiseerde lande gaan stel. Vir die kritiese waarnemer is daar in die botsing tussen Suid-Afrika se uitgangspunte en dié van Brittanje en Japan heelwat stof tot besinning.

In die eerste plek behoort dit duidelik te wees dat daar in enige staatsbestel 'n baie delikate balans behoort te wees tussen die meer gerigte praktiese ondersoek en ontwikkeling enersyds en fundamentele navorsing andersyds. Deur die twee aktiwiteite teen mekaar af te speel, of aan dieselfde waardekriteria te wil meet, lei onafwendbaar tot ' $n$ verskraling en verarming van die navorsingspoging as geheel. Die navorsingskultuur van lande soos Japan wat hom dekades lank ingestem het op tegniese verbetering en ontwikkeling, grotendeels tot uitsluiting van basiese navorsing, gaan nou mank aan 'n gebrek aan ondersoekende denke en intellektuele ontwikkeling. 'n Obsessie met die korttermynresultaat vernietig op 'n subtiele wyse, maar onvermydelik, die ware wese en etos van die wetenskap. Deur sy visie te laat krimp tot die meer onmiddellike toekoms, loop 'n land verder die gevaar om veel van sy navorsingsvernuf en intellektuele kundigheid te verloor. Die inf rastruktuur vir natuurwetenskaplike navorsing word baie langsaam en moeitevol gebou, maar kan op hierdie wyse baie vinnig en maklik afgebreek word.

'n Ware navorsingskultuur is een van die waardevolste onsigbare bates van enige gemeenskap. Dit spruit nie voort uit 'n bloot pragmatiese probleemoplosbenadering nie, maar is ten diepste deel van die Godgegewe kultuuropdrag aan die mens. Dit is inderdaad merkwaardig dat hierdie uitgangspunt, wat enkele geslagte gelede by alle denkende groepe as aksiomaties beskou is, vandag in sekere geselskap met groot argwaan bejeën word. 'n Voorbeeld uit die oseanologie toon duidelik met watter agting fundamentele navorsing slegs 'n paar dekades gelede bejeën is, selfs deur lande wat dit nie breed gehad het nie.

Die afloop van die Eerste Wêreldoorlog was vir Duitsland nie alleen staatkundig en ekonomies katastrofies nie, maar het ook traumaties ingewerk op die waarde wat die Duitse volk aan hulleself as kultuurdraers geheg het. Om hierdie verlies aan selfbeeld teen te werk, is 'n aantal projekte van owerheidsweë aangevoor. Dit is besonder insiggewend dat een van die belangrikste pogings 'n omvangryke navorsingsprojek was. 6 'n Navorsingskip, die nou beroemde Meteor, is toegerus, 'n bemanning en vooraanstaande navorsingspan gewerf en 'n navorsingsvaart van ongeveer twee jaar in die Atlantiese Oseaan uitgevoer wat in omvang sy gelyke voorheen of daarna nie geken het nie. Gegewens wat tydens die Meteorvaart ingesamel is, word na vyftig jaar nog tot op groot hoogte as gesaghebbend beskou.

Wat hier van belang is, is dat daar by die Duitse bewindhebbers geen twyfel bestaan het dat die suksesvolle uitvoering van so 'n grootse fundamentele navorsingsprojek die onomstootlike bewys sou lewer dat die Duitse kultuur geensins deur die verloop van die oorlog vervlak is nie. Dit is ook so deur die wêreldgemeenskap ervaar. By ' $n$ onthaal aan boord van die Meteor tydens 'n besoek aan Kaapstad, het die destydse Eerste Minister van die Unie, genl. Hertzog, die beplanners van hierdie navorsingspoging geloof vir die bewys wat dit gelewer het dat die Duitse volk weer sou herrys en 'n waardige plek tussen die beskaafde kultuurvolke sou inneem. ${ }^{6}$ Selfs met inagneming van die bepaalde tydgees van daardie periode, spreek dit tog boekdele dat fundamentele navorsing destyds onomwonde as kultuurtaak gesien is, 'n taak wat dui op die kwaliteit van 'n gemeenskap se geesteslewe.

In die belangrike gistingsproses wat plaasvind in die denke oor Suid-Afrika se toekoms, onder internasionale politieke druk, maar veral ook onder groot demo- 
grafiese druk, loop ons moontlik die gevaar om die praktiese, nywerheidsgerigte navorsing te oorbeklemtoon tot nadeel van die meer fundamentele. Protagoniste van die bevordering van toegepaste navorsing wend hulle meesal tot allerlei heel pragmatiese kriteria vir die waardebepaling van alle navorsing, kriteria wat nie altyd geldig is ten opsigte van fundamentele navorsing nie. Daar is selfs daadwerklike pogings om befondsing van toegepaste navorsing ten koste van basiese navorsing te laat geskied.

Suid-Afrika se totale navorsingsbegroting as deel van sy bruto nasionale produk was tot kort gelede vergelykbaar met dié van lande soos Zambië. ${ }^{7}$ Die gedeelte van die totale begroting van die WNNR wat in 1986 aan "kennisbevordering" toegewys is, was maar slegs $12 \% .^{8}$ Die jongste gegewens toon verder dat slegs $7 \%$ van die fondse wat in 1983/84 vir navorsing en ontwikkeling in die natuurwetenskappe beskikbaar was, aangewend is vir suiwer basiese navorsing. ${ }^{9}$ Hierdie feite in ag genome bestaan daar duidelike gevaartekens vir die agting wat basiese navorsing in SuidAfrika geniet.

Om homself in 'n veranderende wêreld te handhaaf, het Suid-Afrika sonder enige twyfel 'n dinamiese en doelgerigte toegepaste navorsingsprogram nodig. Sonder gelyktydig verskerpte aandag en befondsing vir fundamentele navorsing word die hele navorsingsboompie egter by die wortels afgesny met geen lang- termyn oorlewingskans nie en word die kwaliteit van ons kultuurlewe oneindig benadeel. Fundamentele navorsing is in 'n Derdewêreldland net so min opsioneel of 'n luukse as wat dit die geval in enige ander land is.

\section{VERWYSINGS}

1. Boekkooi, J. (1987). CSIR "revolution" will produce major changes, The Star, 11 th May 1987.

2. Anonymous (1987). Restoring technological competitiveness, Nature, 326, 437-438.

3. Swinbanks, D. (1987). Japan overtakes Soviet Union in research spending league, Nature, 325, 188.

4. Koshland, D.E. (1986). Science in Japan: a status report, Science, 233, 261.

5. Lynn, L. (1986). Japanese research and technology policy, Science, 233, 296.

6. Spiess, F. (1928). Die Meteor Expedition, Dietrich Reimer, Berlin.

7. Burger, A.P. (1981). $\mathrm{N} \& \mathrm{O}$ in die RSA: stand, neigings, knelpunte en prioriteitsriglyne, S.Afr. Tydskr. Wet., 77, 8-11.

8. Wetenskaplike en Nywerheidnavorsingsraad (1986). Jaarverslag, WNNR, Nr. 41, 70 pp.

9. Departement Nasionale Opvoeding (1987). Hulpbronne vir N \& O. Resultate van Opnameprogram No. 13. Hoofdirektoraat Wetenskapbeplanning, Pretoria, 198 pp.

J.R.E. Lutjeharms

Nasionale Navorsingsinstituut vir Oseanologie, WNNR, Posbus 320, Stellenbosch 7600 